\title{
EVALUASI SENSORI PRODUK COKLAT BATANGAN BERBAHAN BAKU BIJI KOKAO KERING PADA BERBAGAI PERLAKUAN FERMENTASI
}

\author{
Mulono Apriyanto* ${ }^{(1)}$ dan Yulianti ${ }^{(1)}$ \\ (1) Teknologi Pangan, Fakultas Pertanian Universitas Islam Indragiri, \\ Jl. Propinsi Parit 1 Tembilahan, Riau.29213, Indonesia \\ * mulonoapriyanto71@gmail.com
}

\begin{abstract}
Abstrak
Penelitian ini bertujuan untuk mengetahui penerimaan panelis pada coklat batangan yang dihasilkan dari berbagai perlakuan fermentasi pada biji kakao kering jemur. Variasi fermentasi terdiri dua perlakuan yaitu, penambahan inokulum secara bertahap $\left(A_{1}\right)$ dan penambahan inokulum secara serentak diawal fermentasi $\left(A_{2}\right)$. Inokulum yang ditambahkan adalah S. cerevisiae (FNCC 3056), L. lactis (FNC 0086) dan A. aceti (FNCC 0016). Perlakuan kontrol adalah biji kakao kering tanpa fermentasi $\left(\mathrm{A}_{0}\right)$. Lama fermentasi 120 jam selanjutnya biji kakao hasil fermentasi selanjutnya diolah menjadi coklat batang. Coklat batang yang dihasilkan dianalisis secara sensoris meliputi evaluasi rasa sepat, pahit, dan asam serta di uji yang digunakan kandungan polifenol coklat batang. Hasil penelitian menunjukan bahwa terjadi penurunan rasa sepat, pahit dan asam berturut turut dari perlakuan $A_{0}, A_{2}, A_{1}$. Kandungan polifenol tertinggi berturut $\mathrm{A}_{0}, \mathrm{~A}_{2}$, dan $\mathrm{A}_{1}$. Panelis menyatakan coklat batang yang disukai berbahan baku biji kakao perlakuan $\mathrm{A}_{1}$.
\end{abstract}

Kata Kunci : Biji Kakao Kering Jemur, Coklat Batang, Fermentasi.

\section{PENDAHULUAN}

Kakao sebagai salah satu produk perkebunan yang ada di Indragiri Hilir, selama ini oleh petani belum termanfaatkan secara baik. Pengembangan komoditas kakao di beberapa wilayah di Indonesia serta peningkatan produksi tersebut hendaknya diikuti dengan peningkatan mutu biji kakao serta pengembangan ke arah pengolahan hilirnya. Salah satu produk olahan biji kakao adalah coklat batang. Pengolahan coklat batang dipengaruhi oleh biji kakao kering yang digunakan (Rahmadewi dan Purnama, 2019). Coklat batang merupakan salah satu hasil produk hilir yang proses pengolahannya sederhana. Coklat batang yang digunakan sebagai bahan baku pembuatan permen coklat adalah aroma dan rasa. Aroma dan rasa terbentuk karena adanya perubahan kimia dan proses pembentukan flavor pada biji kakao. Penanganan pasca panen biji kakao segar ditingkat petani terdapat macam yaitu biji kakao fermentasi dan biji kakao tanpa fermentasi (Apriyanto., 2017).

Fermentasi merupakan kegiatan penting dalam pembentukan flavor kakao. Fermentasi diawali proses perubahan senyawa gula pada pulp biji 
kakao menjadi asam asetat, yang memberikan peningkatan suhu dan berakibat terjadinya kematian biji (Apriyanto dkk., 2016; Apriyanto dkk., 2017; Apriyanto dan Rujiah, 2018). Selama fermentasi terjadi proses pembentukan rasa, warna dan aroma melalui proses ensimatik, diawali dengan terbentuknya asam-asam organik yang menginduksi proses ensimatik serta proses biokimia menghasilkan perubahan warna dan penurunan senyawa polifenol (Apriyanto dan Chairul., 2019), perubahan secara total biji kakao terfermentasi adalah penurunan berat kering, peningkatan kandungan peptida-N, total gula reduksi dan menurunkan sukrosa serta gula total. Kosentrasi asam amnino bebas (acidic) menurun sejalan meningkatnya kandungan asam amnio total, asam amino bebas hidrofobik (Kongor, Takrama, Budu, Mensah-brown, dan Afoakwa, 2013).

Setelah 7 hari fermentasi kandungan theobromin pada bagian biji (kotiledon) mengalami penurunan dan peningkatan pada bagian kulit (testa), disebabkan migrasi theobromin dari kotelidon ke testa selama fermentasi. Proses migrasi theobromin terjadi $24-48$ jam diawal fermentasi (Flanjak dan Bariši, 2019). Senyawa polifenol selama fermentasi juga mengalami penurunan hingga 53,4\% (Apriyanto dan Chairul, 2019). Biji kakao kaya akan kandungan polifenol memberikan kontribusi rasa sepat pada permen kakao (Rahmadewi dan Purnama, 2019).

Pengeringan biji kakao setelah fermentasi berfungsi untuk menurunkan kadar air pada biji sehingga memperpanjang umur simpan dan menekan tumbuhnya jamur pada biji. Selama proses pengeringan terjadi perkembangan rasa dan warna coklat serta penurunan rasa sepat biji kakao
(Achadijah dan Partha, 2015). Cara pengeringan biji yang berbeda serta proses fermentasi akan mempengaruhi kualitas biji kakao kering dan coklat batang yang dihasilkan. Saat ini, kondisi optimal penanganan biji kakao kering jemur dalam proses penanganan untuk mendapatkan kualitas yang tinggi sangat diperlukan. Tujuan penelitian adalah menentukan pengaruh fermentasi biji kakao tanpa fermentasi dari petani Desa Sanglar, Kecamatan Reteh, Kabupaten Indragiri Hilir menjadi produk coklat batang.

\section{METODOLOGI}

\section{Bahan dan Alat}

Buah kakao varietas forastero diperoleh dari Desa Sanglar, panjang buah $\pm 13 \mathrm{~cm}$, diameter $\pm 6 \mathrm{~cm}$, kulit buah masak optimal berwarna orange, jumlah biji tiap pod \pm 30 keping biji. Bagian pertama Biji kakao segar dikeluarkan dari pot nya kemudian tanpa dicuci dan langsung difermentasi selama 5 hari (120 jam). Bagian kedua buah tanpa dicuci kemudian dibelah untuk dikeluarkan bijinya dan dikeringkan pada cabinet dryer dengan suhu $40^{\circ} \mathrm{C}$ hingga kadar air biji menjadi $15 \%$. Selanjutnya biji kering direndam dalam air dengan perbanging $10 \% \quad(\mathrm{~b} / \mathrm{v})$, selanjutnya difermentasi selama 5 hari (120 jam) secara spontan pada suhu kamar.

Fermentasi biji kakao kering non fermentasi dilakukan pada kotak fermentasi, tiap kotak berisi $10 \mathrm{~kg}$ biji kakao kering non fermentasi. Jumlah biakan murni khamir dan bakteri asam asetat yang ditambahkan $\left(10^{8} \mathrm{CFU} / \mathrm{g}\right)$ berdasarkan jumlah biakan murni yang ditambahkan pada fermentasi kakao biasa (Meersman dkk., 2013). Biakan murni yang digunakan adalah $S$. cerevisiae 
(FNCC 3056), L. lactis (FNC 0086) dan A. aceti (FNCC 0016) dari Laboraturium Mikrobiologi Pusat Studi Pangan dan Gisi Universitas Gadjah Mada.

\section{Metode Penelitian}

Fermentasi yang dilakukan dengan tiga cara yaitu: (1) biji kakao non fermentasi tanpa penambahan biakan murni (kontrol, $\mathrm{A}_{0}$ ), (2) biji kakao ditambahkan campuran biakan murni $\left(\mathrm{A}_{1}\right)$, (3) biji kakao ditambahkan biakan murni secara bertahap diawal fermentasi ditambahkan Saccharomyces cerevisiae setelah jam ke 24 ditambahkan Lactobacillus lactis, kemudian setelah 48 jam ditambahkan Acetobacter aceti $\left(\mathrm{A}_{2}\right)$ (Apriyanto dkk., 2016). Setelah fermentasi selama 5 hari (120 jam) biji kakao dikeringkan dengan dijemur, proses pengeringan dihentikan ketika kadar air biji kakao $\pm 7 \%$ ditandai dengan kulit ari mulai pecah. (4) biji kakao segar difermentasi secara spontan tanpa penambahan biakan murni $\left(\mathrm{A}_{3}\right)$.

Biji kakao kering sebanyak 1000 gram dari masing-masing perlakuan disangrai pada suhu $150^{\circ} \mathrm{C}$ selama 30 menit menggunakan alat penyangrai tipe silinder yang dilengkapi dengan termometer dan termokopel. Alat penyangrai tersebut bergerak secara otomatis dengan kecepatan putar $24 \mathrm{rpm}$. Biji kakao yang telah disangrai selanjutnya dipisahkan kulit bijinya secara manual sehingga diperoleh nib (kotiledon bebas kulit). Nib biji kakao digiling menggunakan blender yang dilanjutkan dengan penghalusan menggunakan penggiling daging hingga terbentuk pasta kasar. Selanjutnya pasta kasar dihaluskan selama 6 jam pada suhu $50^{\circ} \mathrm{C}$. Selama proses penghalusan, dilakukan penambahan lemak kakao (30\%), gula halus (40\%), dan lesitin (0.5\%) (Rahmadewi dan Purnama., 2019).

Pasta yang dihasilkan selanjutnya diturunkan suhunya hingga $27^{\circ} \mathrm{C}$ sambil dilakukan pengadukan kemudian dinaikkan suhunya hingga $30^{\circ} \mathrm{C}$ sambil dilakukan pengadukan. Pencetakan dan pendinginan segera dilakukan setelah tercapai suhu $30^{\circ} \mathrm{C}$. Coklat batang yang dihasilkan dianalisis secara sensoris meliputi rasa sepat, pahit, dan asam serta penerimaan keseluruhan (Machalkova dkk., 2014; Sottnikova dkk., 2016).

Coklat batang yang dihasilkan dianalisa secara sensori meliputi rasa sepat, rasa pahit dan rasa asam serta penerimaan keseluruhan. Panelis yang digunakan adalah panelis tidak terlatih berjumlah 30 orang panelis. Skala penilaian deskriptif: $1=$ amat sangat pahit/sepat/ asam; 2= sangat pahit/sepat/ asam; $3=$ pahit $/$ sepat $/$ asam; $4=$ netral; 5 = agak pahit $/ \mathrm{sepat} / \mathrm{asam} ; 6=$ sangat tidak pahit/sepat/ asam; 7= amat sangat tidak pahit/sepat/ asam. Skala penilaian kesukaan: $1=$ paling tidak disukai hingga $7=$ paling disukai. Data yang didapatkan dianalisa menggunakan Duncan Multiple Range Test (DMRT).

\section{HASIL DAN PEMBAHASAN}

Evaluasi sensoris merupakan uji deskriptif melihat atribut rasa sepat, rasa asam dan rasa pahit coklat batang dari ketiga perlakuan. Hasil uji deskriptif ditampilkan pada Gambar 1. 


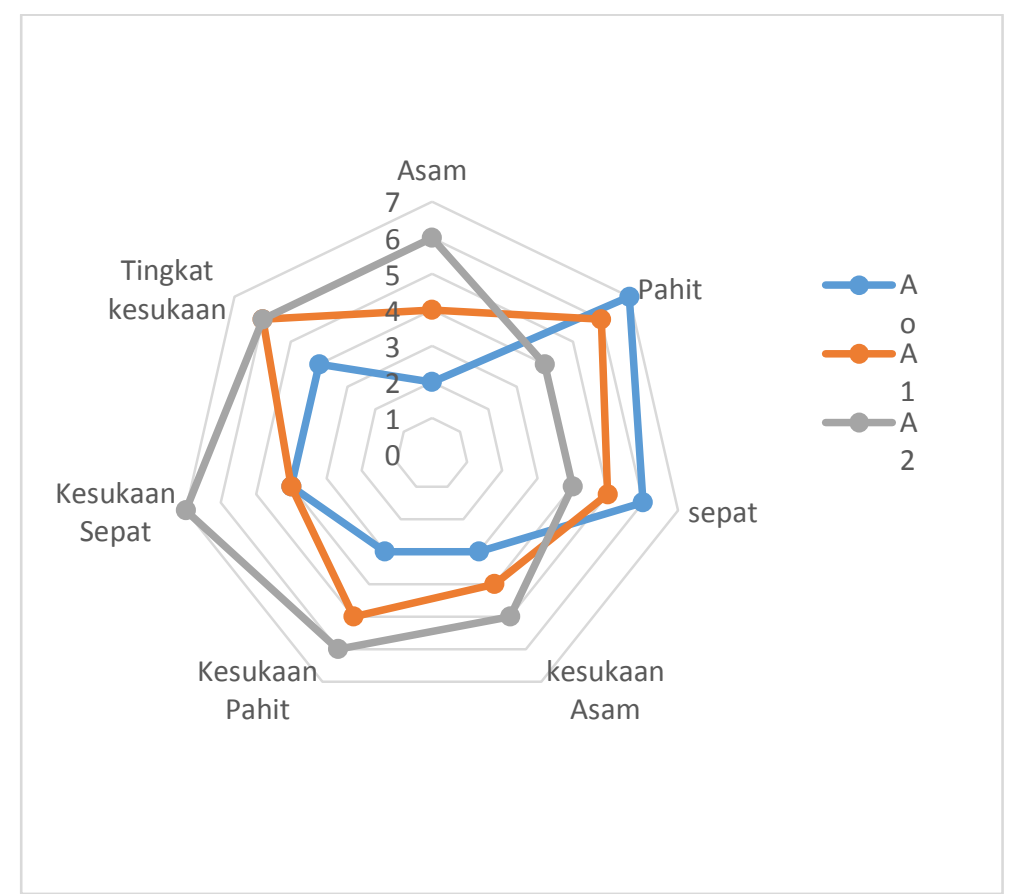

Gambar 1. Hasil Uji Deskriptif Atribut Rasa Asam, Pahit, dan Sepat serta Uji Kesukaan Coklat Batang dari Biji Kakao Kering dalam berbagai variasi fermentasi. [Skala penilaian deskriptif: $1=$ amat sangat pahit/sepat/ asam; $2=$ sangat pahit $/ \mathrm{sepat} / \mathrm{asam} ; 3=$ pahit $/ \mathrm{sepat} / \mathrm{asam} ; 4=$ netral; $5=$ agak pahit/sepat/ asam; $6=$ sangat tidak pahit/sepat $/$ asam; $7=$ amat sangat tidak pahit/sepat/ asam; Skala penilaian kesukaan: 1 = paling tidak disukai hingga $7=$ paling disukai $]$.

\section{Rasa Pahit.}

Hasil uji deskriptif atribut rasa pahit menunjukkan bahwa proses fermentasi perlakuan $\mathrm{A}_{2}$ paling disukai. Coklat batang yang dihasilkan fermentasi perlakuan $A_{0}$ dan $A_{1}$ memberikan sensasi rasa pahit yang lebih tinggi dibandingkan coklat batang dari variasi perlakuan $\mathrm{A}_{2}$ Hal ini sejalan dengan penelitian Rahmadewi dan Darmadji (2019), bahwa fermentasi sempurna menurunkan kadar polipenol. Proses fermentasi akan menurunkan kadar polifenol biji kakao. Menurut Apriyanto dan Umanailo (2019), rasa pahit pada biji kakao sangrai disebabkan oleh kafein, theobromin, dan beberapa 2,5-diketopiperazin. Atribut rasa pahit yang muncul pada pengujian deskriptif coklat batang disebabkan oleh kandungan polifenol dan theobromin.Hal ini sejalan dengan hasil pengujian kadar polifenol pada biji kakao yang terfermentasi seperti penelitian Rahmadewi dan Darmadji, (2018), Apriyanto dan Rujiah, (2018), Apriyanto Mulono et al,. (2017). Selama oksidasi polifenol melalui aktivitas polifenol oksidase (Apriyanto., 2017). Konsentrasi polifenol dalam coklat yang makin tinggi akan meningkatkan rasa pahit dan sepat, sedangkan atribut sensoris yang lainnya tidak dipengaruhi oleh adanya konsentrasi polifenol (Misnawi et al.,. 2004). Atribut rasa pahit ini juga muncul pada coklat yang dibuat dari biji kakao yang berasal dari Papua Nugini, sedangkan coklat sampel Ghana memiliki karakteristik rasa pahit yang sedang (Sukha et al., 2008). Proses fermentasi menurunkan sekitar $40 \%$ 
kandungan theobromin akibat difusi (Apriyanto et al., 2017), sedangkan proses penyangraian biji kakao dalam proses pembuatan coklat batang memberikan penurunan kadar polifenol yang berpengaruh terhadap berkurangnya rasa pahit Polifenol pada produk kakao bertanggung jawab pada pembentukan rasa sepat dan bersamaan dengan alkaloid lain, beberapa asam amino, peptida, dan pirazin berkontribusi pada rasa pahit. Kadar theobromin coklat batang juga memberikan pengaruh terhadap rasa pahit coklat batang.

\section{Rasa Sepat.}

Hasil uji deskriptif atribut rasa sepat menunjukkan bahwa proses fermentasi $\mathrm{A}_{2}$ paling kecil, hal ini ditunjukan oleh penelitian (Misnawi et al., 2004) bahwa tingginya konsentrasi polifenol dalam biji kakao memberikan pengaruh pada rasa pahit dan sepat dari coklat batang yang dihasilkan. Menurut Apriyanto dan Rujiah., (2018) bahwa perlakuan penambahan inokulum secara bertahap menghasilkan biji kakao dengan kadar polifenol paling rendah. Berdasarkan pengujian sensori coklat batang yang dihasilkan menunjukan rasa pahit dan rasa sepat semakin rendah. Kandungan polifenol biji kakao kering dapat teridentifikasi kadarnya melalui pengujian sensoris berdasarkan rasa sepat yang dirasakan. Coklat batang non fermentasi memberikan sensasi rasa sepat yang lebih tinggi dibandingkan coklat batang fermentasi (Rahmadewi dan Purnama Darmaji, 2019). Sejalan penelitian (Rahmadewi dan Darmadji, 2018) bahwa proses fermentasi dan cara pengeringan memberikan pengaruh secara nyata pada sensasi sepat yang dirasakan. Hal ini menunjukkan bahwa proses pengolahan biji kakao kering menjadi coklat batang tidak mengurangi atribut rasa sepat secara maksimal.

\section{Rasa Asam.}

Karakteristik rasa asam coklat batang yang dihasilkan tertinggi pada perlakuan $\mathrm{A}_{2}$ dibandingkan pada perlakuan yang lain. Hal ini menunjukan bahwa selama fermentasi akan terbentuk senyawa asam asetat pada biji kakao dan memberikan sensasi rasa asam pada coklat batang. Pada peneltian sebelumnya (Apriyanto 2016), (Apriyanto Mulono et al., 2017), (Apriyanto dan Rujiah, 2018) menunjukan bahwa diakhir proses fermentasi kosentrasi asam asetat pada biji kakao yang difermentasi dengan variasi perlakuan penambahan inokulum secara bertahap $\left(\mathrm{A}_{2}\right)$ tertinggi. Akibat adanya proses fermentasi pulp menghasilkan asam-asam organik dan asam tersebut berdifusi ke dalam biji selama proses fermentasi. Asam yang berada di dalam biji tersebut belum dapat hilang secara sempurna selama proses pengeringan. Pada coklat batang yang dibuat dari biji kakao perlakuan $\mathrm{A}_{0}$ dan $A_{1}$ tidak menunjukkan adanya deteksi rasa asam dengan intensitas kuat. Proses pengolahan biji kakao kering menjadi coklat batang belum dapat menghilangkan asam dalam biji sehingga coklat batang yang dihasilkan masih berasa asam. Perlakuan $\mathrm{A}_{0}$ menghasilkan coklat batang memberikan sensasi rasa asam yang lebih rendah dibandingkan coklat batang yang lain.

\section{Tingkat Kesukaan.}

Hasil uji ranking menunjukkan bahwa variasi proses fermentasi akan memberikan tingkat kesukaan rasa asam, pahit, sepat, dan keseluruhan yang berbeda terhadap coklat batang yang dihasilkan. Coklat batang perlakuan fermentasi $\mathrm{A}_{2}$ menunjukan kesukaan tertinggi dibanding perlakuan yang lain. Hal ini sejalan penelitian (Apriyanto et 
al., 2017), (Rahmadewi dan Purnama Darmaji, 2019) tingginya kandungan polifenol pada coklat batang yang dibuat dari biji kakao kering non fermentasi yang menghasilkan sensasi rasa pahit dan sepat lebih tinggi sehingga panelis tidak menyukai. Evaluasi kesukaan dilakukan dengan uji ranking pada produk coklat batang. Uji kesukaan terhadap atribut rasa asam, pahit, dan sepat serta kesukaan keseluruhan yang dilakukan menunjukkan hasil bahwa proses fermentasi memberikan tingkat kesukaan rasa asam, pahit, sepat, dan keseluruhan yang berbeda terhadap coklat batang yang dihasilkan.

Coklat batang hasil perlakuan $\mathrm{A}_{2}$ memberikan sensasi rasa pahit dan sepat yang lebih disukai dibandingkan coklat batang hasil perlakuan $A_{0}$ dan $A_{1}$, sedangkan kesukaan panelis terhadap rasa asam tidak menunjukkan adanya perbedaan antara perlakuan fermentasi. Secara keseluruhan, coklat batang hasil pelakuan $\mathrm{A}_{1}$ lebih disukai oleh panelis dibandingkan coklat batang dari perlakuan $\mathrm{A}_{0}$ dan $\mathrm{A} 1$.

\section{KESIMPULAN DAN SARAN}

Coklat batang yang dibuat dari biji kakao perlakuan $\mathrm{A}_{1}$ memiliki rasa asam, pahit, dan sepat yang lebih sedikit serta lebih diterima dan disukai panelis dibandingkan dengan coklat batang dari biji kakao perlakuan $\mathrm{A}_{0}$ dan $\mathrm{A}_{2}$. Proses pembuatan coklat batang tidak memberikan pengaruh besar pada kandungan polipenol biji kakao sehingga rasa pahit dan rasa sepat coklay batang sangat dipengaruhi keberhasilan proses fermentasi biji kakao.

\section{DAFTAR PUSTAKA}

Achadijah, Siti, and Ida Bagus Banyuro Partha. 2015. Hasil Penelitian Mempelajari Kualitas Biji Kakao Kering Yang Beredar Di Pasaran Daerah Istimewa Yogyakarta Dan Kemungkinan Pengolahan Lanjutan. Agroteknose 6(2).

Apriyanto, Mulono. 2016. Changes in Chemical Properties of Dreid Cocoa ( Theobroma Cacao ) Beans during Fermentation. Intl. J. Food. Ferment. Technol 5(1): 11-16.

Apriyanto, Mulono. 2017. Perubahan $\mathrm{pH}$, Keasaman dan Indeks Fermentasi Biji Kakao Selama Fermentasi Hasil Biji Kakao (Theobroma cacao). Jurnal Teknologi Pertanian 6(1): 12-18.

Apriyanto, Mulono, $\mathrm{M}$ Chairul, and Basrun Umanailo. 2019. Decrease Polyphenols, Ethanol, Lactic Acid, and Acetic Acid during Fermentation with Addition of Cocoa Beans Innoculum. International Journal of Scientific \& Technology Research 8(10): 461-65. www.ijstr.org.

Apriyanto, Mulono, and Rujiah Rujiah. 2018. Penurunan Total Polifenol, Etanol, Asam Laktat, Asam Asetat, dan Asam Amino Selama Fermentasi Biji Kakao Asalan dengan Penambahan Inokulum. Jurnal Gizi dan Dietetik Indonesia (Indonesian Journal of Nutrition and Dietetics) 5(1): 1.

Apriyanto, Mulono, S Sutardi, Eni Harmayani, and S Supriyanto. 2016. Perbaikan Proses Fermentasi Biji Kakao Non Fermentasi dengan Penambahan Biakan Murni Saccharomyces cerevisiae, Lactobacillus lactis, dan Acetobacter Aceti. AGRITECH 36(4). 
Apriyanto Mulono, Sutardi, Supriyadi, and Eni Harmayani. 2017. Fermentasi Biji Kakao Kering Menggunakan

Saccharomycescerevisiae, Lactobacillus Lactis, Acetobacter Aceti. AGRITECH 37(3): 302-11.

Apriyanto, Mulono, Sutardi Sutardi, Supriyanto Supriyanto, and Eni Harmayani. 2017. Amino Acid Analysis of Cocoa Fermented by High Performance Liquid Chromatography (HPLC). Asian Journal of Dairy and Food Research.

Flanjak, Ivana, and Veronika Bariši. 2019. The Chemistry behind Chocolate Production. Molecules 24(3163): 1-13.

Kongor, John Edem et al. 2013. Effects of Fermentation and Drying on the Fermentation Index and Cut Test of Pulp Pre-Conditioned Ghanaian Cocoa (." Journal of Food Science and Engineering 3(October 2015): 625-34.

Machalkova, Lenka, Ludek Hrivna, Sarka Nedomova, and Miroslav Juzl. 2014. The Effect of Storage Temperature and Production Method of Chocolate Confectionery on Changes in Its Quality. MENDELNET: 417-22.

Meersman, Esther et al. 2013. Detailed Analysis of the Microbial Population in Malaysian
Spontaneous Cocoa Pulp Fermentations Reveals a Core and Variable Microbiota. PLOS ONE 8(12).

Misnawi, S. Jinap, Jamilah, and S. Nazamid. 2004. Sensory Properties of Cocoa Liquor as Affected by Polyphenol Concentration and Duration of Roasting. Food Quality and Preference 15(5): 403-9.

Rahmadewi, Yunda Maymanah, and Purnama Darmadji. 2018. Pengaruh Penjemuran dan Pengering Mekanis terhadap $\mathrm{pH}$, Total Polifenol, dan Kandungan Gula Biji Kakao dan Coklat Batang dari Biji Kakao Rakyat. Rekayasa Pangan dan Pert 6(2): 124-30.

Rahmadewi, Yunda Maymanah, and Purnama Darmaji. 2019. Evaluasi Sensoris Coklat Batang dari Biji Kakao Rakyat dengan Kondisi Fermentasi dan Pengeringan yang Berbeda. Jurnal Dunia Gizi 2(1): 56-62.

Sottnikova, Viera. 2016. Effect of Storage Regime on Texture And Other Sensory Properties Of Chocolate. MENDELNET: 64550. 